DOI: https://doi.org/10.24127/ajpm.v10i4.4178

\title{
KEMAMPUAN LITERASI MATEMATIKA SISWA SMA PADA KONTEKS PENDIDIKAN DAN PEKERJAAN DITINJAU DARI KEMAMPUAN AWAL
}

\author{
Zaidah Nurul Hasanah $^{1}$, Budi Usodo ${ }^{2}$, Dewi Retno Sari Saputro ${ }^{3}$ \\ ${ }^{1,2,3}$ Universitas Sebelas Maret, Surakarta, Indonesia \\ *Corresponding author. \\ E-mail: $\quad$ zaidahnurulhasanah@student.uns.ac.id ${ }^{1)}$ \\ budiusodo@staff.uns.ac.id ${ }^{2)}$ \\ $\underline{\text { dewiretnoss@staff.uns.ac.id }}^{3}$
}

Received 30 August 2021; Received in revised form 17 November 2021; Accepted 27 December 2021

\begin{abstract}
Abstrak
Literasi matematika adalah kemampuan individu untuk merumuskan, menggunakan, dan menafsirkan matematika dalam berbagai konteks. Kemampuan literasi matematika pada dimensi konteks dibedakan menjadi empat yaitu konteks pribadi, konteks pendidikan dan pekerjaan, konteks sosial, dan konteks ilmiah. Penelitian ini bertujuan untuk mendeskripsikan kemampuan literasi matematika siswa SMA pada konteks pendidikan dan pekerjaan. Metode yang digunakan dalam penelitian ini adalah deskriptif kualitatif. Subjek penelitian adalah tiga siswa kelas X SMA Negeri 1 Sragen dengan kategori kemampuan awal matematika rendah, sedang, dan tinggi. Instrumen penelitian yang digunakan adalah tes, wawancara, dan peneliti. Metode pengumpulan data yang digunakan dalam penelitian adalah metode tes dan metode wawancara. Validasi data yang digunakan adalah metode triangulasi. Hasil tes dan wawancara kemudian dianalisis menggunakan indikator kemampuan literasi matematika untuk memperoleh data kemampuan literasi matematika dalam memecahkan masalah. Hasil penelitian menunjukkan kemampuan literasi matematika siswa kemampuan awal matematika rendah, sedang, tinggi pada konteks pendidikan dan pekerjaan adalah rendah. Pada soal literasi matematika pada konteks pendidikan dan pekerjaan siswa kemampuan awal matematika rendah, sedang, tinggi memiliki kemampuan menafsirkan masalah, menerapkan strategi pemecahan masalah sederhana yang prosedural tetapi belum mampu memenuhi kemampuan merepresentasi jawaban dan berbeda dan mengkomunikasikan penyelesaian.
\end{abstract}

Kata kunci: Kemampuan awal matematika; konteks pendidikan dan pekerjaan; literasi matematika.

\begin{abstract}
Mathematical literacy is an individual's ability to formulate, use, and interpret mathematics in a variety of contexts. Mathematical literacy ability in context dimension is divided into four, namely personal context, educational and work context, social context, and scientific context. This study aims to describe the mathematical literacy ability of high school students in the context of education and work. The method used in this research is descriptive qualitative. The subjects of the study were three grade X students of SMA Negeri 1 Sragen with low, medium, and high initial mathematical ability categories. The research instruments used were tests, interviews, and researchers. The data collection methods used in the study were the test method and the interview method. Validation of the data used is the triangulation method. The results of the tests and interviews were then analyzed using indicators of mathematical literacy ability to obtain data on mathematical literacy skills in solving problems. The results showed that the students' mathematical literacy skills were low, medium, high in the context of education and work were low. In the case of mathematical literacy in the context of education and work, students with low, medium, and high early mathematical abilities have the ability to interpret problems, apply simple procedural problem solving strategies but have not been able to fulfill the ability to represent different and different answers and communicate solutions.
\end{abstract}

Keywords: Early mathematical ability; educational and work context; mathematical literacy.

This is an open access article under the Creative Commons Attribution 4.0 International License 
DOI: https://doi.org/10.24127/ajpm.v10i4.4178

\section{PENDAHULUAN}

Pendidikan nasional adalah pendidikan yang berlandaskan Pancasila dan UUD Negara Republik Indonesia Tahun 1945 yang berakar pada nilainilai agama, kebudayaan nasional Indonesia dan tanggap terhadap tuntutan perubahan zaman. Keterlibatan Indonesia dalam Program for International Student Assessment (PISA) merupakan salah satu usaha untuk mengetahui bagaimana kondisi pendidikan Indonesia dibanding negara lain. Dalam PISA 2018 menempatkan Indonesia berada pada peringkat ke-7 dari bawah, artinya kemampuan literasi matematika Indonesia masih berada diposisi rendah dibandingkan negara lain. Hasil PISA tersebut diperkuat oleh penelitian yang telah dilakukan oleh Khoirudin, Setyawati, \& Nursyahida (2017) bahwa literasi matematika siswa Indonesia dikategorikan masih rendah yaitu hanya mampu menghadapi masalah literasi matematika level satu.

Literasi matematika (OECD, 2018) didefinisikan sebagai kemampuan individu untuk merumuskan, menggunakan dan menafsirkan matematika dalam berbagai konteks. Menyelesaikan soal kemampuan literasi matematika membutuhkan siklus pemikiran matematika yang meliputi pola pemecahan masalah, menalar secara logis, mengkomunikasikan dan menjelaskan (Stacey \& Turner, 2015). Kemampuan literasi matematika siswa meliputi tiga dimensi yaitu: 1) isi atau konten matematika; 2) situasi dan konteks; dan 3) proses yang dilakukan untuk menyelesaikan suatu masalah. Pada dimensi situasi dan konteks literasi matematika dibedakan menjadi empat item yaitu pribadi, pendidikan dan pekerjaan, sosial, dan ilmiah. Khikmiyah \& Midjan (2017) menyatakan bahwa konteks pendidikan dan pekerjaan pada literasi matematika berkaitan dengan kehidupan peserta didik di sekolah dan atau di lingkungan tempat bekerja.

Hasil penelitian yang dilakukan oleh Pranitasari \& Ratu (2020) disalah satu SMA Negeri banyak dijumpai siswa melakukan kesalahan dalam menyelesaikan soal literasi matematika. Beberapa siswa yang secara akademis nilai matematika tinggi tampak mengalami kebingungan menyelesaikan soal literasi matematika. Pernyataan itu diperkuat oleh Nguyen, Ta, \& Tran (2019) bahwa beberapa siswa yang pandai matematika disekolah belum tentu bagus dalam literasi matematika. Karena dalam proses pembelajaran disekolah siswa belum terbiasa dengan menyelesaikan soal bertipe PISA (Murtiyasa, Rejeki, \& Ishartono, 2020).

Penelitian yang dilakukan oleh Putri, Sumardani, Rahayu, Hajizah \& Rahman (2020) menyatakan bahwa rendahnya kemampuan literasi matematika dikarenakan siswa mengalami kesulitan merumuskan masalah kehidupan sehari-hari ke dalam bentuk model matematika. Selain itu menurut Suharyono \& Rosnawati (2020) salah satu penyebab kemampuan literasi matematika rendah karena siswa dalam proses pemecahan masalah masih terpaku pada rumus yang telah mereka hafalkan tanpa memahami konteks masalah yang diberikan. Lestari \& Putri (2020) mengungkapkan bahwa siswa dengan kemampuan literasi rendah merasa kurang yakin terhadap jawaban mereka sendiri karena masalah yang hadapi terlalu sulit. Rahmawati, Usodo, \& Fitriana (2021) menyatakan bahwa literasi rendah disebabkan siswa masih mengalami kesulitan dalam mengkomunikasikan dan merepresentasikan masalah ke dalam konteks. 
DOI: https://doi.org/10.24127/ajpm.v10i4.4178

Namun dari penelitian-penelitian tersebut belum banyak yang melakukan analisis terhadap kemampuan literasi matematika siswa SMA pada konteks pendidikan dan pekerjaan pada tingkat kemampuan awal rendah, sedang, dan tinggi. Padahal berdasarkan data di lapangan tingginya hasil belajar matematika belum bisa menjamin bahwa kemampuan literasi matematika siswa juga tinggi.

Berdasarkan uraian diatas, maka diperlukan analisis mendalam terkait kemampuan literasi matematika siswa. Oleh karena itu, tujuan dari penelitian ini yaitu menganalisis kemampuan literasi matematika siswa kelas X SMA pada konteks pendidikan dan pekerjaan ditinjau dari kemampuan awal matematis.

\section{METODE PENELITIAN}

Metode yang digunakan dalam penelitian ini adalah deskriptif kualitatif. Sebelum diberikan tes, siswa dikelompokkan berdasarkan kemampuan awal matematis (KAM). Pengelompokan bertujuan untuk mengetahui kemampuan awal dan kemudian dikelom-pokkan menjadi 3 kategori yaitu rendah, sedang, dan tinggi. Kiteria pengelompokan KAM (Novitasari, 2015) ada pada Tabel 1. Subjek penelitian adalah siswa SMA Negeri 1 yang dipilih masing-masing 1 siswa KAM tinggi, sedang, dan rendah untuk diwawancara.
Tabel 1. Kriteria Pengelompokan KAM

\begin{tabular}{cc}
\hline Nilai KAM & Kategori KAM \\
\hline$K A M \geq \bar{x}+S B$ & Tinggi \\
$\bar{x}-S B \leq K A M<\bar{x}+S B$ & Sedang \\
$K A M<\bar{x}-S B$ & Rendah \\
\hline
\end{tabular}

Keterangan:

$\bar{x} \quad=$ Skor Rerata

SB $=$ Simpangan Baku

Teknik pengum-pulan data menggunakan teknik tes dan wawancara untuk mengumpulkan data serta informasi tentang kemampuan literasi matematika siswa SMA pada konteks pekerjaan. Tes terdiri dari 3 butir soal esai dengan indikator kemampuan literasi matematika level 2, 3, dan 4 pada konteks pendidikan dan pekerjaan. Butir soal disusun berdasarkan standar PISA dan divalidasi oleh para ahli dan direvisi. Validasi data yang digunakan adalah metode triangulasi.

Hasil tes dianalisis menggunakan indikator kemampuan literasi matematika pada konteks pekerjaan kemudian dicek dengan wawancara untuk memperoleh data kemampuan literasi matematika. Analisis data dilakukan secara terus menerus sampai diperoleh data tuntas. Untuk menganalisis kemampuan literasi matematika konteks pendidikan pekerjaan digunakan indikator kemampuan literasi matematika menurut PISA 2018 pada Tabel 2.

Tabel 2. Indikator Kemampuan Literasi Matematika Menurut PISA (OECD, 2018)

Level Indikator

Siswa dapat mengidentifikasi hubungan antara informasi tekstual dan data

2 yang relevan untuk dipecahkan masalah, menafsirkan, menerapkan model sederhana, serta menggunakan representasi tunggal siswa dapat memilih dan menerapkan strategi pemecahan masalah yang sederhana. Siswa pada tingkat ini dapat menafsirkan masalah, menggunakan rumus tertentu, dan menggunakan penalaran sederhana. 
DOI: https://doi.org/10.24127/ajpm.v10i4.4178

\begin{tabular}{cl}
\hline Level & \multicolumn{1}{c}{ Indikator } \\
\hline 4 & $\begin{array}{l}\text { siswa mampu dapat menafsirkan masalah, memilih, menerapkan strategi } \\
\text { pemecahan masalah yang komplek. Mengintegrasikan representasi yang } \\
\text { berbeda serta dapat mengomunikasikan penyelesaiannya. }\end{array}$ \\
\hline
\end{tabular}

\section{HASIL DAN PEMBAHASAN}

Hasil penelitian diperoleh dari tes kemampuan literasi matematika siswa pada konteks pendidikan dan pekerjaan dan wawancara. Tes diberikan dalam bentuk soal esai konteks pendidikan dan pekerjaan yang terdiri dari soal level 2, level 3 dan level 4. Berikut adalah soal tes kemampuan literasi matematika siswa konteks pendidikan dan pekerjaan:

1. Butir soal tes kemampuan literasi konteks pendidikan dan pekerjaan level 2 berkaitan dengan kemampuan siswa dalam mengidentifikasi hubungan antara informasi tekstual dan data yang relevan untuk dipecahkan masalah, menafsirkan, menerapkan model sederhana, serta menggunakan representasi tunggal. Berikut butir soal tes kemampuan literasi matematika konteks pendidikan dan pekerjaan level 2 pada Gambar 1.

Sebuah perusahaan handphone membuat 3 tipe, yaitu tipe $X$, tipe $Y$, dan tipe $Z$. Di akhir produksi, handphone diuji dan ketiganya terjadi kesalahan dan dikembalikan untuk diperbaiki. Tabel berikut menunjukkan jumlah rata-rata setiap tipe handphone yang diproduksi setiap hari, dan rata-rata presentase kerusakan per hari.

\begin{tabular}{|c|c|c|}
\hline $\begin{array}{c}\text { Tipe } \\
\text { Handphone }\end{array}$ & $\begin{array}{c}\text { Jumlah Rata-Rata } \\
\text { Produksi Perhari }\end{array}$ & $\begin{array}{c}\text { Persentase Rata- } \\
\text { Rata Kesalahan }\end{array}$ \\
\hline X & 2000 & $3 \%$ \\
\hline Y & 4000 & $4 \%$ \\
\hline Z & 4000 & $5 \%$ \\
\hline
\end{tabular}

Apakah pertanyaan dibawah ini benar?
\begin{tabular}{|l|c|}
\hline \multicolumn{1}{|c|}{ Pernyataan } & $\begin{array}{c}\text { Apakah pernyataan } \\
\text { benar atau salah }\end{array}$ \\
\hline $\begin{array}{l}2 / 5 \text { dari handphone yang } \\
\text { diproduksi adalah tipe Z }\end{array}$ & Benar/salah \\
\hline $\begin{array}{l}\text { Setiap penumpukan 200 tipe Y } \\
\text { yang dibuat, tepat } 8 \text { mengalami } \\
\text { kesalahan produksi }\end{array}$ & Benar / salah \\
\hline $\begin{array}{l}\text { Jika tipe X dipilih secara acak } \\
\text { setiap hari untuk di uji, } \\
\text { kemungkinan harus diperbaiki } \\
\text { adalah } 0,03\end{array}$ & Benar/salah \\
\hline
\end{tabular}

Gambar 1. Soal Level 2
2. Butir soal tes kemampuan literasi konteks pendidikan dan pekerjaan level 3 berkaitan dengan kemampuan siswa dalam memilih dan menerapkan strategi pemecahan masalah yang sederhana. Siswa pada tingkat ini dapat menafsirkan masalah, menggunakan rumus tertentu, dan menggunakan penalaran sederhana. Berikut butir soal tes kemampuan literasi matematika konteks pendidikan dan pekerjaan level 3 pada Gambar 2.

Rudi seorang pekerja proyek akan merenovasi sebuah taman indoor. Taman tersebut terdapat kolam ikan, area batu alam, dan kursi santai.

Rudi ingin menutup lantai taman dengan rumput sintetis.

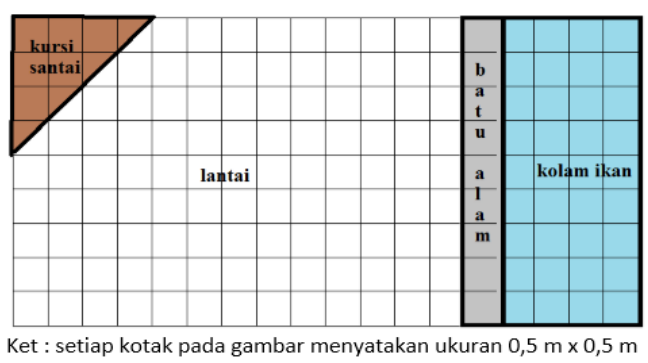

Berapa total rumput yang dibutuhkan untuk menutup lantai taman?

\section{Gambar 2. Soal Level 3}

3. Butir soal tes kemampuan literasi konteks pendidikan dan pekerjaan level 4 berkaitan dengan kemampuan siswa dalam menafsirkan masalah, memilih, menerapkan strategi pemecahan masalah yang komplek. Meng-integrasikan representasi yang berbeda serta dapat mengomunikasikan penyelesaiannya. Berikut butir soal tes kemampuan literasi matematika konteks pendidikan dan pekerjaan level 4 pada Gambar 3. 
DOI: https://doi.org/10.24127/ajpm.v10i4.4178

Budi akan membuat kolam ikan lele semi permanen yang berbentuk balok terbuat dari bambu dan terpal. Budi membutuhkan $32 \mathrm{~m}$ batang bambu untuk membuat kerangka kolam ikan tersebut. Kolam tersebut mempunyai panjang yang lebih dari lebar dan tinggi $1 \mathrm{~m}$. Berapa banyak air yang digunakan untuk mengisi kolam hingga penuh?

\section{Gambar 3. Soal Level 4}

Berikut adalah hasil analisis kemampuan literasi matematika pada konteks pendidikan dan pekerjaan dari 3 orang siswa dengan 1 siswa KAM rendah, 1 siswa KAM sedang, dan 1 siswa KAM tinggi.

\section{Subjek 1 (S1) Siswa dengan KAM Rendah}

Subjek dengan KAM rendah diwakili oleh siswa S1 menjawab soal literasi matematika konteks pekerjaan level 2 seperti pada Gambar 4.

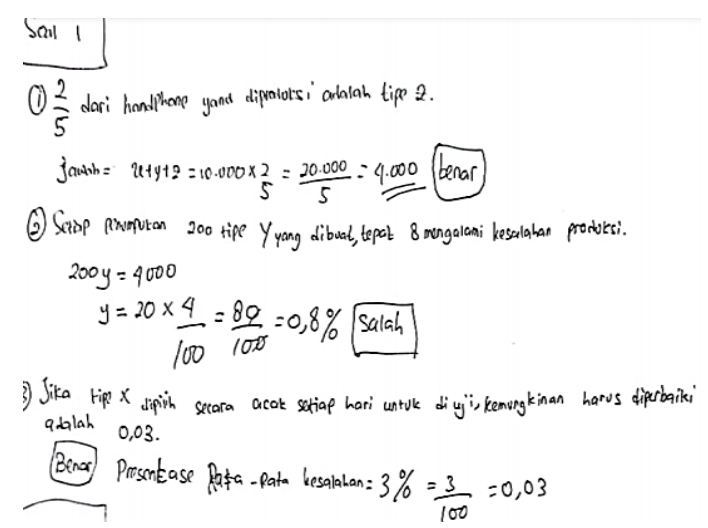

Gambar 4. Jawaban KAM rendah untuk level 2

Berdasarkan Gambar 4 dan wawancara, S1 tidak menuliskan apa yang diketahui tetapi berdasarkan wawancara s1 dapat menjelaskan apa informasi yang diperoleh dari soal. S1 menuliskan yang ditanya. Selain itu dalam S1 dapat mengidentifikasi hubungan antara informasi masalah dengan informasi yang disampaikan pada soal, S1 dapat menafsirkan penyelesaian dengan baik untuk pertanyaan 1 dan 3 dengan menerapkan model sederhana, serta menggunakan representasi tunggal. Tetapi untuk pertanyaan 2, S1 melakukan kesalahan dalam menerapkan penyelesaian suatu persamaan.

S1 menjawab soal literasi matematika konteks pekerjaan level 3 seperti pada Gambar 5.

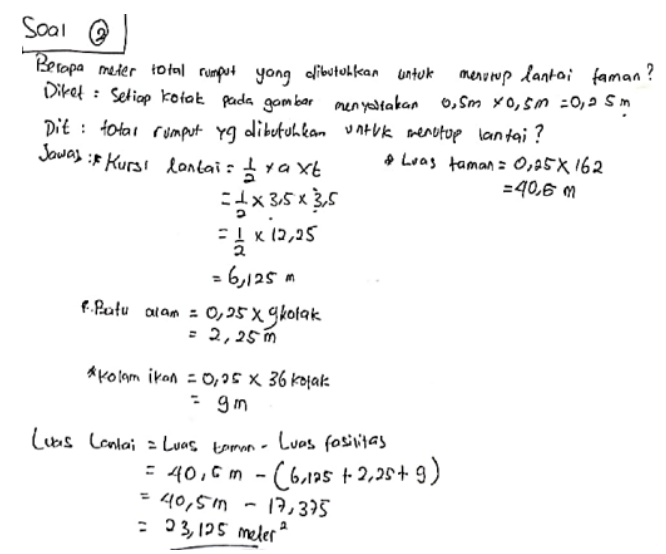

Gambar 5. Jawaban KAM rendah untuk level 3

Berdasarkan Gambar 5 dan wawancara, S1 memahami apa yang diketahui dan apa yang ditanyakan pada soal. S1 dapat memilih rumus untuk luas bangun datar, seperti luas kursi yang berbentuk segitiga, luas kolam ikan yang berbentuk persegi panjang. Dalam wawancara S1 merasa tidak yakin terhadap jawabannya sendiri, S1 kesulitan menyampaikan strategi penyelesaian yang telah dilakukan walaupun dari jawaban yang ditulis S1 telah menuliskan strategi pemecahan masalah yang dipilih. S1 menggunakan penalaran sederhana untuk mencari banyak karpet yang dibutuhkan hanya saja S1 melakukan kesalahan dalam perhitungan.

S1 menjawab soal literasi matematika konteks pekerjaan level 4 seperti pada Gambar 6. 
DOI: https://doi.org/10.24127/ajpm.v10i4.4178

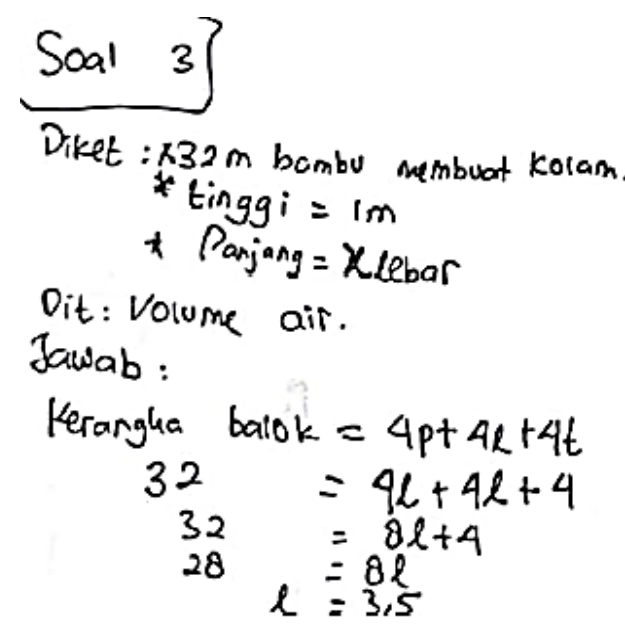

Gambar 6. Jawaban KAM rendah untuk level 4

Berdasarkan Gambar 5 dan wawancara, S1 menyatakan bahwa merasa kesulitan untuk mengerjakan soal tersebut dan S1 merasa ragu terhadap jawabannya. S1 dapat menuliskan apa yang diketahui dari masalah tetapi tidak tepat dan dapat menuliskan apa yang ditanyakan, hal tersebut menunjukkan S1 belum mampu menafsirkan masalah. S1 menganggap panjang dan lebar kolam itu sama panjangnya, hal tersebut adalah salah. S1 memilih rumus kerangka balok, tetapi pada penafsiran masalah di awal tidak tepat menyebabkan penyelesaian yang dilakukan juga salah. S1 menyerah untuk menyelesaikan masalah tersebut, S1 tidak menyampaikan representasi penyelesaian yang berbeda serta tidak mengomunikasikan penyelesainya.

\section{Subjek 2 (S2) Siswa Dengan KAM Sedang}

Subjek dengan KAM sedang diwakili oleh siswa S2 menjawab soal literasi matematika konteks pekerjaan level 2 seperti pada Gambar 7. Berdasarkan Gambar 7 dan wawancara, S2 memahami apa yang diketahui dan apa yang ditanya. Selain itu dalam S2 dapat menggunakan berbagai informasi untuk menafsirkan penyelesaian dengan baik. S2 sudah mampu menerapkan model pemecahan sederhana untuk ketiga pertanyaan tersebut, yaitu perbandingan untuk pertanyaan 1 , melakukan operasi pada perbandingan senilai untuk pertanyaan 2, dan mengkonversi persen ke bentuk desimal.

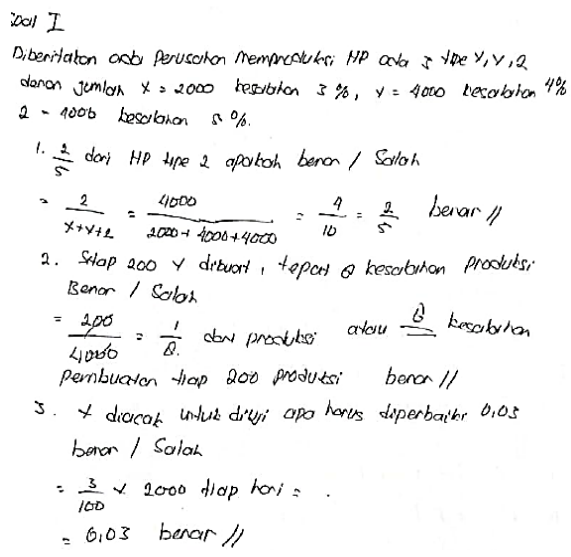

Gambar 7. Jawaban KAM Sedang untuk Level 2

S2 menjawab soal literasi matematika konteks pekerjaan level 3 seperti pada Gambar 8.

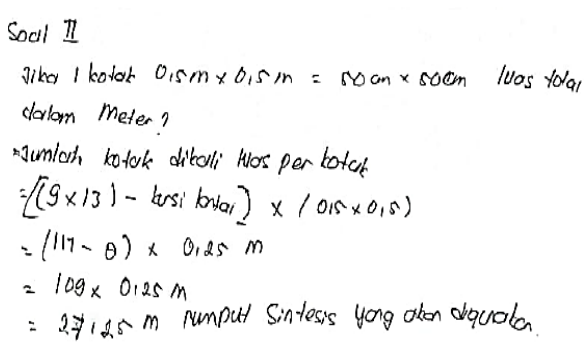

Gambar 8. Jawaban KAM Sedang untuk level 3

Berdasarkan Gambar 8 dan wawancara, S2 dapat memahami apa yang diketahui dan apa yang ditanyakan pada soal. S2 memilih dan menerapkan strategi sederhana dengan menghitung banyak kotak secara manual. Kemudian S2 menggunakan penalaran sederhana dengan menggunakan rumus luas satuan kotak. S2 melakukan penyelesaian masalah dengan baik tetapi terdapat 
DOI: $\underline{\text { https://doi.org/10.24127/ajpm.v10i4.4178 }}$

kesalahan dalam menuliskan satuan dari luas. S2 menjawab soal literasi matematika konteks pekerjaan level 4 seperti pada Gambar 9.

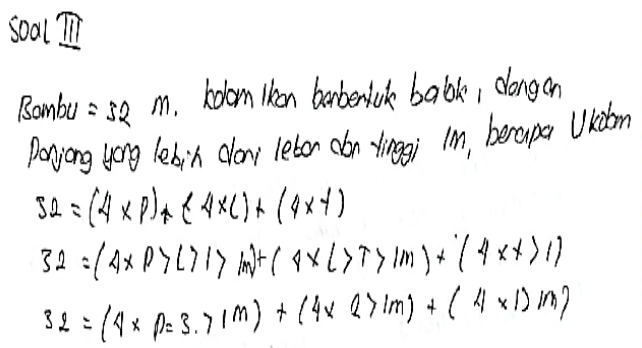

Gambar 9. Jawaban KAM sedang untuk level 4

Berdasarkan Gambar 9 dan wawancara, S2 memahami apa yang diketahui dan apa yang ditanyakan, hal tersebut menunjukkan S2 mampu menafsirkan masalah. S2 menggunakan rumus kerangka balok dengan tepat, namun merasa kesulitan dalam melakukan strategi penyelesaian hal tersebut terlihat dari hasil substitusi panjang dan lebar kerangka yang tidak jelas. S2 juga tidak melanjutkan penyelesaiannya untuk masalah level 4 ini, sehingga dapat dikatakan S2 tidak representasi penyelesaian yang berbeda serta tidak mengomunikasikan penyelesaiannya.

\section{Subjek 3 (S3) Siswa Dengan KAM Tinggi}

Subjek dengan KAM tinggi diwakili oleh siswa S3 menjawab soal literasi matematika konteks pekerjaan level 2 seperti pada Gambar 10. 
DOI: https://doi.org/10.24127/ajpm.v10i4.4178

Berdasarkan Gambar 10 dan wawancara, S3 memahami apa yang ketahui pada soal dan apa yang ditanya walaupun tidak menuliskannya secara jelas. S3 mampu menafsirkan masalah dan melakukan penyelesaian masalah dengan baik dengan menerapkan konsep perbandingan. Pada jawaban S3 nampak bahwa sangat rinci dalam menuliskan penyelesaian dan mengkomunikasikan jawabannya.

S3 menjawab soal literasi matematika konteks pekerjaan level 3 seperti pada Gambar 11.

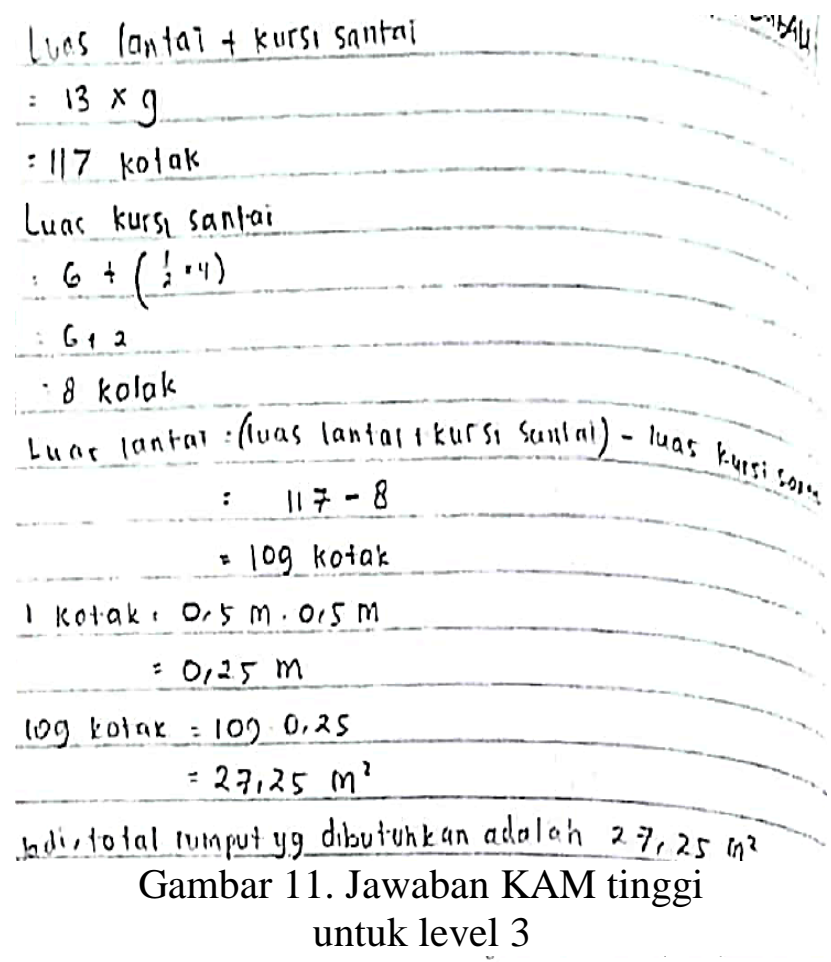

Berdasarkan Gambar 11 dan wawancara, S3 memahami apa yang diketahui dan apa yang ditanyakan pada soal. S3 memilih dan menerapkan strategi pemecahan masalah dengan baik hal tersebut terlihat bahwa S3 dapat menafsirkan masalah, mampu mencari banyaknya kotak pada lantai dengan menggunakan rumus luas persegi panjang dan segitiga. S3 menjelaskan bagaimana dia menggunakan penalaran untuk mencari banyak rumput yang dibutuhkan dengan cara banyak kotak dikali luas tiap satuan kotak.

S3 menjawab soal literasi matematika konteks pekerjaan level 4 seperti pada Gambar 12.

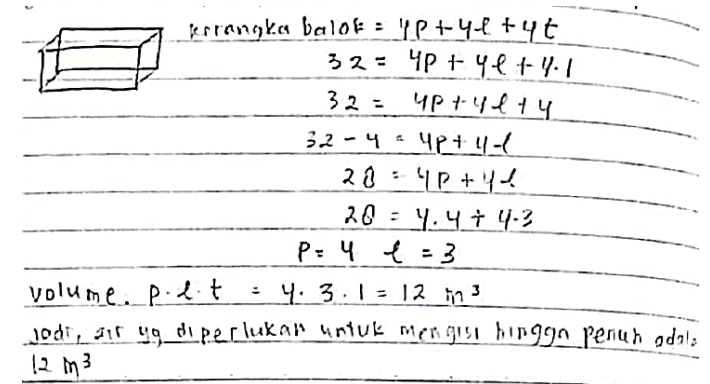

Gambar 12. Jawaban KAM tinggi untuk level 4

Berdasarkan Gambar 12 dan wawancara, S3 memahami apa yang diketahui dan apa yang ditanya walapun tidak dituliskan dalam jawaban, S3 menggambar sebuah balok untuk mempermudah dalam menafsirkan masalah. S3 menggunakan rumus kerangka balok dengan tepat dan 
melakukan strategi penyelesaian dengan cara mensubstitusi informasi soal bahwa tingginya adalah $1 \mathrm{~m}$. S3 melakukan penyelesaian dengan strategi coba-coba untuk mencari panjang dan lebar. S3 tidak mampu menafsirkan jawaban lain dan tidak menggunakan representasi dari sumber yang berbeda.

Siswa kategori KAM rendah hanya mampu menyelesaikan soal literasi matematika dalam konteks pendidikan dan pekerjaan untuk level 2. Siswa KAM rendah kesulitan untuk menyelesaikan soal level 3 dan 4 , ia justru menyerah pada soal level 4 . Hal tersebut sesuai dengan penelitian yang dilakukan oleh Nurani, Riyadi, \& Subanti (2021) yang menyatakan bahwa siswa yang merasa kesulitan dalam mengerjakan soal, cenderung memilih untuk tidak mengerjakan. Siswa KAM rendah belum mampu menafsirkan masalah dengan baik, melakukan kesalahan dalam menerapkan strategi pemecahan masalah, tidak mampu mengkomunikasikan representasi yang berbeda. Hal tersebut dapat disimpulkan bahwa siswa kategori KAM rendah memiliki kemampuan literasi matematika juga rendah dalam konteks pendidikan dan pekerjaan

Siswa kategori KAM sedang mampu menyelesaikan soal literasi matematika dalam konteks pendidikan dan pekerjaan untuk level 2 dan level 3. Untuk soal level 4 kesulitan dalam melakukan strategi penyelesaian. Seperti halnya hasil penelitian yang dilakukan Natsir \& Munfarikhatin (2021) mengatakan bahwa kemampuan literasi matematika rendah siswa disebabkan karena kemampuan siswa masih kurang dalam menemukan strategi menyelesaikan masalah.

Siswa kategori KAM tinggi mampu menyelesaikan soal literasi matematika dalam konteks pendidikan dan pekerjaan untuk level 2, 3. Siswa KAM tinggi dapat memahami masalah dengan baik, dapat menentukan strategi penyelesaian, dan dapat mengomunikasikan pemecahan masalah dengan baik. Seperti halnya hasil penelitian yang dilakukan oleh Romli (2017) siswa dengan kemampuan matematika tinggi dapat mengemukakan langkah-langkah penyelesaian masalah dengan benar dengan menggunakan strategi penyelesaian yang telah dipahami dari masalah. Hanya saja dalam menyelesaikan soal level 4, siswa KAM tinggi tidak memberikan representasi jawaban yang berbeda dari masalah tersebut.

Berdasarkan uraian diatas, walaupun jawaban siswa KAM tinggi lebih baik dari jawaban siswa KAM sedang, jawaban siswa KAM sedang lebih baik dari siswa KAM rendah, tetapi secara keseluruhan siswa kategori KAM rendah, sedang tinggi memiliki kemampuan literasi matematika rendah pada konteks pendidikan dan pekerjaan.

Hal tersebut terlihat dari kebiasaan siswa menjawab secara prosedural dan belum terbiasa dengan soal yang membutuhkan solusi aplikatif dengan menyampaikan representasi penyelesaian yang berbeda. Hasil penelitian ini juga diperkuat oleh hasil penelitian yang dilakukan oleh Muzaki (2019) yang menyatakan bahwa siswa baik tergolong kategori KAM tinggi, sedang dan rendah memiliki kemampuan literasi rendah karena siswa dalam menyelesaikan soal yang masih terbiasa dengan jawaban prosedural, konkret dan siswa belum terbiasa dengan soal yang membutuhkan solusi yang aplikatif. Untuk meningkatkan kemampuan literasi matematika siswa SMA pada konteks pendidikan dan pekerjaan perlu mempertimbangkan 
kemampuan awal matematika yang siswa miliki dan memperhatikan kesalahan yang sering dilakukan dalam menyelesaikan masalah.

\section{KESIMPULAN DAN SARAN}

Berdasarkan hasil dan pembahasan dapat disimpulkan bahwa kemampuan literasi matematika siswa KAM rendah, sedang, tinggi pada konteks pendidikan dan pekerjaan adalah rendah. Pada soal literasi matematika pada konteks pendidikan dan pekerjaan siswa KAM rendah, sedang, tinggi memiliki kemampuan menafsirkan masalah, menerapkan strategi pemecahan masalah sederhana yang prosedural tetapi belum mampu memenuhi kemampuan merepresentasi jawaban dan berbeda dan mengkomunikasikan penyelesaian. Dari hasil penelitian ini, saran untuk penelitian selanjutnya untuk melakukan penelitian yang lebih mendalam mengingat pentingnya literasi matematika. Peneliti juga memberikan saran ke pada guru untuk mengembangkan bahan ajar untuk meningkatkan kemampuan literasi matematika siswa.

\section{DAFTAR PUSTAKA}

Khikmiyah, F., \& Midjan, M. (2017). Pengembangan Buku Ajar Literasi Matematika untuk Pembelajaran di SMP. JURNAL SILOGISME: Kajian Ilmu Matematika Dan Pembelajarannya, 1(2), 15-26. https://doi.org/10.24269/js.v1i2.2 75

Khoirudin, A., Setyawati, R. D., \& Nursyahida, F. (2017). Menyelesaikan Soal Berbentuk Pisa. Aksioma, 8(2), 33-42.

Lestari, N., \& Putri, R. I. I. (2020). Using the Palembang's Local Context in PISA-Like
Mathematics Problem for Analyze Mathematics Literacy Ability of Students. Jurnal Pendidikan Matematika, 14(2), 169-182. https://doi.org/10.22342/jpm.14.2. 6708.169-182

Murtiyasa, B., Rejeki, S., \& Ishartono, N. (2020). Profile o f Students ' Error in Solving Mathematics Word Problems Based on PISA Frameworks. ATLANTIS PRESS, 467(Semantik 2019), 135-137.

Muzaki, A. (2019). Analisis Kemampuan Literasi Matematis Siswa. Mosharafa: Jurnal Pendidikan Matematika. 8(3), 493-502.

Natsir, I., \& Munfarikhatin, A. (2021). Analisis Kemampuan Literasi Matematika Siswa Berdasarkan Multiple Intelligence dalam Menyelesaikan Soal Matematika. 10(1), 273-283. https://ojs.fkip.ummetro.ac.id/inde x.php/matematika/article/view/33 84

Nguyen, A., Nguyen, D., Ta, P., \& Tran, T. (2019). Preservice Teachers Engage in a Projectbased Task: Elucidate Mathematical Literacy in a Reformed Teacher Education Program. International Electronic Journal of Mathematics Education, 15(1), 657-666. https://doi.org/10.29333/iejme/57 78

Novitasari, D. (2015). Penerapan Pendekatan Pembelajaran Creative Problem Solving (CPS) sebagai Upaya Meningkatkan Kemampuan Berpikir Kritis Matematis Siswa. Jurnal Pendidikan Matematika \& Matematika, 1(1), 43-56. https://jurnal.umj.ac.id/index.php/ fbc/article/view/1627/1380 
DOI: https://doi.org/10.24127/ajpm.v10i4.4178

Nurani, M., Riyadi, R., \& Subanti, S. (2021). Profil Pemahaman Konsep Matematika Ditinjau Dari Self Efficacy. AKSIOMA: Jurnal Program Studi Pendidikan Matematika, 10(1), 284. https://doi.org/10.24127/ajpm.v10 i1.3388

OECD. (2018). PISA 2018 released financial literacy items. August, $1-27$. http://www.oecd.org/pisa/test/

Pranitasari, D., \& Ratu, N. (2020). Analisis Kesalahan Siswa Dalam Menyelesaikan Soal Matematika PISA pada Konten Change snd Relationship. AKSIOMA: Jurnal Program Studi Pendidikan Matematika, 9(4), 1235-1248.

Putri, A., Sumardani, D., Rahayu, W., Hajizah, M. N., \& Rahman, A. (2020). Kemampuan Literasi Matematika Menggunakan Bar Model pada Materi Aljabar. AKSIOMA: Jurnal Program Studi Pendidikan Matematika, 9(2), 338-347.

Rahmawati, W. a., Usodo, B., \& Fitriana, D. L. (2021). Mathematical Literacy Skills Students of the Junior High School in Solving PISA-Like Mathematical Problems. IOP Conference Series: Earth and Environmental Science, 1808(1). https://doi.org/10.1088/17426596/1808/1/012045

Romli, M. (2017). Profil Koneksi Matematis Siswa Perempuan SMA Dengan Kemampuan Matematika Tinggi dalam Menyelesaikan Masalah Matematika. JIPMat, 1(2), 145157.

https://doi.org/10.26877/jipmat.v1 i2.1241
Stacey, K., \& Turner, R. (2015). Assessing mathematical literacy: The PISA experience. Assessing Mathematical Literacy: The PISA Experience, $1-321$. https://doi.org/10.1007/978-3319-10121-7

Suharyono, E., \& Rosnawati, R. (2020). Analisis Buku Teks Pelajaran Matematika SMP ditinjau dari Literasi Matematika. Mosharafa: Jurnal Pendidikan Matematika, 9(3), 451-462. 